\title{
Community-specific impacts of exotic earthworm invasions on soil carbon dynamics in a sandy temperate forest
}

\author{
Jasmine M. Crumsey, ${ }^{1,4}$ James M. Le Moine, ${ }^{1}$ Yvan Capowiez, ${ }^{2}$ Mitchell M. Goodsitt, ${ }^{3}$ Sandra C. Larson, ${ }^{3}$ \\ George W. Kling, ${ }^{1}$ and Knute J. Nadelhoffer ${ }^{1}$ \\ ${ }^{1}$ Department of Ecology and Evolutionary Biology, 2019 Kraus Natural Science Building, 830 North University Avenue, \\ University of Michigan, Ann Arbor, Michigan 48109 USA \\ ${ }^{2}$ INRA, UR 1115 Plantes et Systèmes Horticoles, 84914 Avignon Cedex 09, France \\ ${ }^{3}$ Department of Radiology, 1500 East Medical Center Drive, University of Michigan, Ann Arbor, Michigan 48109 USA
}

\begin{abstract}
Exotic earthworm introductions can alter above- and belowground properties of temperate forests, but the net impacts on forest soil carbon (C) dynamics are poorly understood. We used a mesocosm experiment to examine the impacts of earthworm species belonging to three different ecological groups (Lumbricus terrestris [anecic], Aporrectodea trapezoides [endogeic], and Eisenia fetida [epigeic]) on $\mathrm{C}$ distributions and storage in reconstructed soil profiles from a sandy temperate forest soil by measuring $\mathrm{CO}_{2}$ and dissolved organic carbon (DOC) losses, litter $\mathrm{C}$ incorporation into soil, and soil $\mathrm{C}$ storage with monospecific and species combinations as treatments. Soil $\mathrm{CO}_{2}$ loss was $30 \%$ greater from the Endogeic $\times$ Epigeic treatment than from controls (no earthworms) over the first 45 days; $\mathrm{CO}_{2}$ losses from monospecific treatments did not differ from controls. DOC losses were three orders of magnitude lower than $\mathrm{CO}_{2}$ losses, and were similar across earthworm community treatments. Communities with the anecic species accelerated litter C mass loss by 31-39\% with differential mass loss of litter types (Acer rubrum $>$ Populus grandidentata $>$ Fagus grandifolia $>$ Quercus rubra $\geq$ Pinus strobus) indicative of leaf litter preference. Burrow system volume, continuity, and size distribution differed across earthworm treatments but did not affect cumulative $\mathrm{CO}_{2}$ or DOC losses. However, burrow system structure controlled vertical $\mathrm{C}$ redistribution by mediating the contributions of leaf litter to A-horizon $\mathrm{C}$ and $\mathrm{N}$ pools, as indicated by strong correlations between (1) subsurface vertical burrows made by anecic species, and accelerated leaf litter mass losses (with the exception of P. strobus); and (2) dense burrow networks in the A-horizon and the $\mathrm{C}$ and $\mathrm{N}$ properties of these pools. Final soil $\mathrm{C}$ storage was slightly lower in earthworm treatments, indicating that increased leaf litter $\mathrm{C}$ inputs into soil were more than offset by losses as $\mathrm{CO}_{2}$ and $\mathrm{DOC}$ across earthworm community treatments.
\end{abstract}

Key words: Aporrectodea trapezoides; community composition; Eisenia fetida; exotic earthworm; Lumbricus terrestris; soil carbon storage; temperate forest; University of Michigan Biological Station.

\section{INTRODUCTION}

European earthworm introductions into northern U.S. temperate forests have attracted increased attention during the past decade. Although endemic earthworms have been slow to recolonize the northern U.S. temperate forests from which they were extirpated during the last glacial advance (James 1995), human activities in the past century have led to introductions of peregrine earthworm species, such as Dendrobaena octaedra, Lumbricus rubellus, L. terrestris, Aporrectodea caliginosa and A. trapezoides (Holdsworth et al. 2007). Dense earthworm invasions have shifted understory plant diversity, increased leaf litter decay rates, and diminished forest floor horizons (Bohlen et al. 2004b,

Manuscript received 10 September 2012; revised 6 May 2013; accepted 23 May 2013; final version received 14 June 2013.

Corresponding Editor: R. D. Evans.

${ }^{4}$ E-mail: jcrumsey@umich.edu
Hale et al. 2006, Frelich et al. 2006, Holdsworth et al. 2007, Sackett et al. 2012). Invasions have also been linked to decreased soil C stocks (Scheu 1997, Burtelow et al. 1998, Bohlen et al. 2004b, Marhan and Scheu 2006, Eisenhauer et al. 2007), soil C redistribution (Burtelow et al. 1998, Bohlen et al. 2004a, Wironen and Moore 2006, Straube et al. 2009), and increased soil $\mathrm{CO}_{2}$ emissions (Marhan and Scheu 2006). While impacts on subsets of forest ecosystem functions and properties have been described, community-specific impacts of earthworm invasions on forest soil $\mathrm{C}$ cycling and net $\mathrm{C}$ storage are less understood.

Earthworm invasions in forest ecosystems can involve multiple species (Araujo et al. 2004, Fisk et al. 2004, Wironen and Moore 2006, Eisenhauer et al. 2007, Costello and Lamberti 2009) with diverse feeding, dispersal, and burrowing behaviors (Bouché 1977, Lee 1985, Jégou et al. 1998b, Hale et al. 2005, Curry and Schmidt 2006). Interspecific interactions (Jégou et al. 
2000, Capowiez et al. 2001, Whalen and Costa 2003) can, in turn, mediate earthworm community impacts on forest ecosystem properties and processes (Wolters 2000, Uvarov 2009). However, direct tests of how earthworm species interactions mediate impacts on forest soil C dynamics and storage are limited (Hale et al. 2005, Postma-Blaauw et al. 2006, Straube et al. 2009).

In this study, we examined monospecific and multispecies earthworm community impacts on $\mathrm{C}$ loss and $\mathrm{C}$ redistribution in reconstructed forest soil profiles with mixed-species leaf litter (Oi) horizons representative of temperate forests on sandy soils in the Upper Great Lakes region, USA. We report the results of a mesocosm experiment in which earthworm species of three functional groups (Lumbricus terrestris L., Aporrectodea trapezoides Dugès, and Eisenia fetida Savigny) were combined in a factorial design. Over one year, we measured carbon dioxide $\left(\mathrm{CO}_{2}\right)$ and dissolved organic carbon (DOC) losses, and related $\mathrm{C}$ losses to earthworm species combinations. At the end of the experiment, we (1) assessed relationships between subsurface burrow system structure and soil C budget components, and (2) quantified net changes in soil $\mathrm{C}$ storage. We expected that impacts on $\mathrm{CO}_{2}$ and DOC outputs, leaf litter $\mathrm{C}$ inputs, and net $\mathrm{C}$ storage would be mediated by earthworm community composition, and that burrow system properties would be related to $\mathrm{C}$ redistribution in soil profiles.

\section{Methods \\ Experimental design}

We conducted a mesocosm experiment from August 2009 to August 2010 in a belowground laboratory (Lussenhop et al. 1991) at the University of Michigan Biological Station, Cheboygan County, USA (UMBS; see Appendix A for study area description), using seven combinations of three exotic earthworm species present in forest soils as treatments and no-earthworm controls in uniform leaf litter and soil profiles. Adults of the earthworm species representing different functional groups included: L. terrestris [anecic, which are litter feeding and vertical burrowing], A. trapezoides [endogeic, mineral soil feeding and dwelling], and E. fetida [epigeic, litter feeding and surface dwelling]. Treatments, hereafter capitalized, included species monocultures: Epigeic Alone, Endogeic Alone, and Anecic Alone; and mixed treatments: Epigeic $\times$ Anecic, Epigeic $\times$ Endogeic, Endogeic $\times$ Anecic, and All Species. Earthworm biomass additions were higher than observed in field surveys $\left(21 \pm 2.66 \mathrm{~g} / \mathrm{m}^{2}\right.$ fresh mass [mean $\pm \mathrm{SE}]$ ), but allowed for the scaled additions of anecic species across monocultures and mixed treatments. Earthworm biomass amounts were also within ranges of values reported in similar northern temperate forests (e.g., Hale et al. 2005, Suárez et al. 2006). Earthworm biomass was constant at $20 \pm 0.5 \mathrm{~g}$ (fresh mass) per mesocosm. Earthworm biomass was $20 \pm 0.5 \mathrm{~g}$ in species monocultures, $10 \pm$
$0.5 \mathrm{~g}$ of each species in two-species treatments, and 6.5 $\pm 0.5 \mathrm{~g}$ of each species in the All Species treatment. Biomass additions in monocultures corresponded to 27 \pm 1 endogeic earthworms per mesocosm, $31 \pm 1$ epigeic earthworms per mesocosm, and 3 anecic earthworms per mesocosm.

Mesocosms were contained in 20-L plastic buckets (20 $\mathrm{cm}$ diameter and $30 \mathrm{~cm}$ depth). Soil profiles were constructed by adding $25 \mathrm{~kg}$ (fresh mass) of sieved and homogenized B-horizon material packed to a bulk density of $2.5 \mathrm{~g} / \mathrm{cm}^{3}$, and $5 \mathrm{~kg}$ (fresh mass) of sieved and homogenized A-horizon material packed to a bulk density of $1.3 \mathrm{~g} / \mathrm{cm}^{3}$. Leaf litter additions were scaled from area-normalized leaf litter data of the UMBS AmeriFlux site in 2008 (C. S. Vogel, unpublished data). Leaf litter additions from overstory tree species summed to $16.5 \mathrm{~g}: 41 \%$ Populus grandidentata, $32 \%$ Acer rubrum, $21 \%$ Quercus rubra, $4 \%$ Fagus grandifolia, and $2 \%$ Pinus strobus (Table 1).

\section{Mesocosm C loss measurements ( $\mathrm{CO}_{2}$ and $\mathrm{DOC}$ )}

Soil $\mathrm{CO}_{2}$ efflux was measured from August 2010 to June 2011 (25 times over a 320-day period). Measurements were taken daily in week one, and three times in week two when burrow production and initial soil redistribution likely occurred (Jégou et al. 1998a, 2000, Capowiez et al. 2011); weekly during early fall and spring months when earthworm activity is highest (Callaham and Hendrix 1997); and monthly during late fall and winter months when earthworm activity and soil $\mathrm{CO}_{2}$ efflux is lowest (Toland and Zak 1994, Davidson et al. 1998). $\mathrm{CO}_{2}$ efflux was measured using an infrared gas analyzer (IRGA, LICOR-6400; LICOR Biosciences, Lincoln, Nebraska, USA) connected to an air-tight lid placed on each mesocosm. In a 4.67-L headspace, air flowed in a closed loop to the LI-6400, temperature was measured with a type E thermocouple (Omega, Stamford, Connecticut USA), and a capillary tube was inserted for air pressure equilibration. Soil $\mathrm{CO}_{2}$ efflux rates $\left(F_{\mathrm{c}}\right)$ were determined by measuring $10 \mu \mathrm{mol} / \mathrm{mol}$ change in $\mathrm{CO}_{2}$ concentration $\left(\Delta \mathrm{CO}_{2}\right)$ over a 20 -s measurement period, from which $\mathrm{CO}_{2}-\mathrm{C}$ loss rate per unit soil surface area was calculated as

$$
F_{\mathrm{c}}=\frac{\left(\frac{\Delta \mathrm{CO}_{2}}{\Delta t}\right)\left(\frac{P V_{t}}{R T}\right)}{S}
$$

where $F_{\mathrm{c}}$ is corrected for headspace volume $(V)$ and surface area $(S)\left(\mu \mathrm{mol} \mathrm{CO} C_{2} \cdot \mathrm{m}^{-2} \cdot \mathrm{s}^{-1}\right), t$ is time, $P$ is atmospheric pressure $(\mathrm{kPa}), R$ is the universal gas constant, and $T$ is temperature $\left({ }^{\circ} \mathrm{C}\right) \cdot \mathrm{CO}_{2}$ efflux values were integrated to derive cumulative curves for each mesocosm.

Soil moisture was maintained at field capacity with $500 \mathrm{~mL}$ deionized water additions. Soil leachates collected from zero-tension lysimeters installed below each mesocosm were weighed, filtered using glass-fiber filters (Whatman, $\mathrm{GF} / \mathrm{F}$ ), acidified with $6 \mathrm{~mol} / \mathrm{L} \mathrm{HCl}$, 
TABLE 1. Initial leaf litter, A-horizon, and B-horizon $\mathrm{C}$ and $\mathrm{N}$ properties.

\begin{tabular}{lcccr}
\hline \hline \multicolumn{1}{c}{ Pool } & $\mathrm{C}\left(\mathrm{g} / \mathrm{m}^{2}\right)$ & \multicolumn{1}{c}{$\% \mathrm{C}$} & $\% \mathrm{~N}$ & \multicolumn{1}{c}{$\mathrm{C}: \mathrm{N}$} \\
\hline Leaf litter & $128(0.26)$ & $47.9(<0.01)$ & $0.65(<0.01)$ & $74.2(0.03)$ \\
Acer rubrum & $39.68(0.06)$ & $46.5(0.4)$ & $0.5(0.04)$ & $98.8(<0.01)$ \\
Pinus strobus & $2.01(0.01)$ & $50.3(0.03)$ & $0.4(0.01)$ & $137.6(<0.01)$ \\
Populus grandidentata & $53.65(0.24)$ & $49.2(0.6)$ & $0.8(0.1)$ & $62.7(<0.01)$ \\
Quercus rubra & $27.25(0.07)$ & $47.9(0.4)$ & $0.6(0.03)$ & $74.2(<0.01)$ \\
Fagus grandifolia & $5.44(0.02)$ & $45.7(0.5)$ & $0.7(0.06)$ & $62.2(<0.01)$ \\
Bulk soil & $2882(67.57)$ & $1.14(0.08)$ & $0.05(<0.01)$ & $22.02(0.13)$ \\
A-horizon & $994(42.31)$ & $1.56(0.07)$ & $0.07(<0.01)$ & $21.7(0.31)$ \\
B-horizon & $1761(35.53)$ & $0.6(0.01)$ & $0.03(<0.01)$ & $22.4(0.28)$ \\
\hline
\end{tabular}

Notes: Values represent means, with SE in parentheses; $n=6$.

and stored at $-20^{\circ} \mathrm{C}$ until analyzed for DOC concentration using an Aurora (Model 1030) OI Analytical TOC analyzer (OI Analytical, College Station, Texas USA). DOC loss values were integrated to derive cumulative curves for each mesocosm.

\section{Three-dimensional reconstruction and quantification of burrow systems}

Soils containing earthworm treatments were imaged using X-ray computed tomography (X-ray CT; GE Discovery CT 750 HD scanner [General Electric Healthcare, Waukesha, Wisconsin USA], $140 \mathrm{kV}, 500$ $\mathrm{mA}, 1 \mathrm{~s}, 0.984: 1$ pitch, $1.25-\mathrm{mm}$ slice interval, $1.25-\mathrm{mm}$ slice thickness, $0.78 \mathrm{~mm} X$ and $Y$ resolution, $40 \mathrm{~cm}$ field of view, Bone reconstruction filter) at the School of Radiology, University of Michigan Hospital (Ann Arbor, Michigan, USA). The sequential analysis of two-dimensional binarized images enables three-dimensional tracking of earthworm burrows and subsequent three-dimensional volumetric reconstructions of the burrow systems (Fig. 1). Image preparation and quantification of burrow continuity, volume, and size distribution followed methods previously described (Capowiez et al. 2001, Pierret et al. 2002, Bastardie et al. 2005).

\section{Litter and soil sampling, $C$ and $N$ content}

Mesocosms were destructively harvested by first collecting intact leaf litter remaining on the soil surface. Soils were excavated by first removing A-horizon soil, followed by removal of B-horizon soil that was separated into burrow and non-burrow soil (i.e., soil not visibly altered by earthworm burrowing activity or ingestion). Separation of burrow and non-burrow soil in the A-horizon was not feasible due to highly dense burrow networks across treatments (Fig. 1). Pool subsamples were weighed fresh, dried at $60^{\circ} \mathrm{C}$, weighed again to obtain dry-mass corrections, and pulverized for $\mathrm{C}$ and $\mathrm{N}$ analyses using a $\mathrm{CN}$ elemental analyzer (Elemental Analyzer 1030; Costech Analytical Technologies, Valencia, California, USA). Species-specific leaf litter mass losses were used in calculating a weighted average of composite leaf litter $\mathrm{C}$ and $\mathrm{N}$ properties expressed at the end of the experiment.

\section{Soil C mass storage}

We used an elemental mass balance equation to calculate net changes in soil $\mathrm{C}$ storage as follows:

$$
\Delta C=\left(L_{\mathrm{c}}+E\right)-\left(\int_{0}^{320} F_{c}(t) d t+\int_{0}^{320} \operatorname{DOC}_{\mathrm{EX}}(t) d t\right)
$$

where $\Delta C$ is the net storage of $\mathrm{C}$ inputs to soil as leaf litter mass loss (i.e., from the soil surface) across control and earthworm treatments $\left(L_{\mathrm{c}}\right)$ plus earthworm biomass not recovered at the end of the experiment $(E)$, minus $\mathrm{C}$ outputs via 320-d cumulative $\mathrm{CO}_{2}$ efflux ( $F_{\mathrm{c}}$ in Eq. 1 ), plus dissolved organic $\mathrm{C}$ export $\left(\mathrm{DOC}_{\mathrm{EX}}\right)$. Minor $\mathrm{C}$ fluxes occurring in aerobic upland forest soils, including $\mathrm{CH}_{4}$ consumption (Castro et al. 1995, Le Mer and Roger 2001), and dissolved inorganic C export (Kaiser and Zech 1998), were not measured in this study.

\section{Statistical analyses}

We used Kruskal-Wallis $H$ tests $(H, \mathrm{df}=7, n=32, \alpha=$ 0.05 ) with nonparametric multiple comparisons to assess treatment differences in soil $\mathrm{C}$ budget components, burrow system variables, and soil $\mathrm{C}$ storage. To assess treatment effects on $\mathrm{CO}_{2}$ and DOC loss over time, we used a general linear model (GLM) with repeated measures, followed by Bonferroni-corrected pairwise comparisons of cumulative curves. We used Spearman rank correlations ( $\rho, n=32, \alpha=0.05)$ to characterize relationships among soil $\mathrm{C}$ budget components and among burrow system variables. Soil $\mathrm{C}$ budget component and burrow system variable associations were characterized using co-inertia analysis (CoIA), which identifies co-relationships between two ecological data matrices first transformed, in this case, by principal component analysis (Doledec and Chessel 1994, Dray et al. 2003). Statistical significance of the CoIA was assessed by Monte Carlo permutation tests (999 permutations; $P<0.05)$. Statistics were done in $\mathrm{R}$ v2.15.2 (R Development Core Team 2012) on RStudio v0.96.331 (available online), ${ }^{5}$ using the packages ade 4

${ }^{5}$ www.rstudio.com 

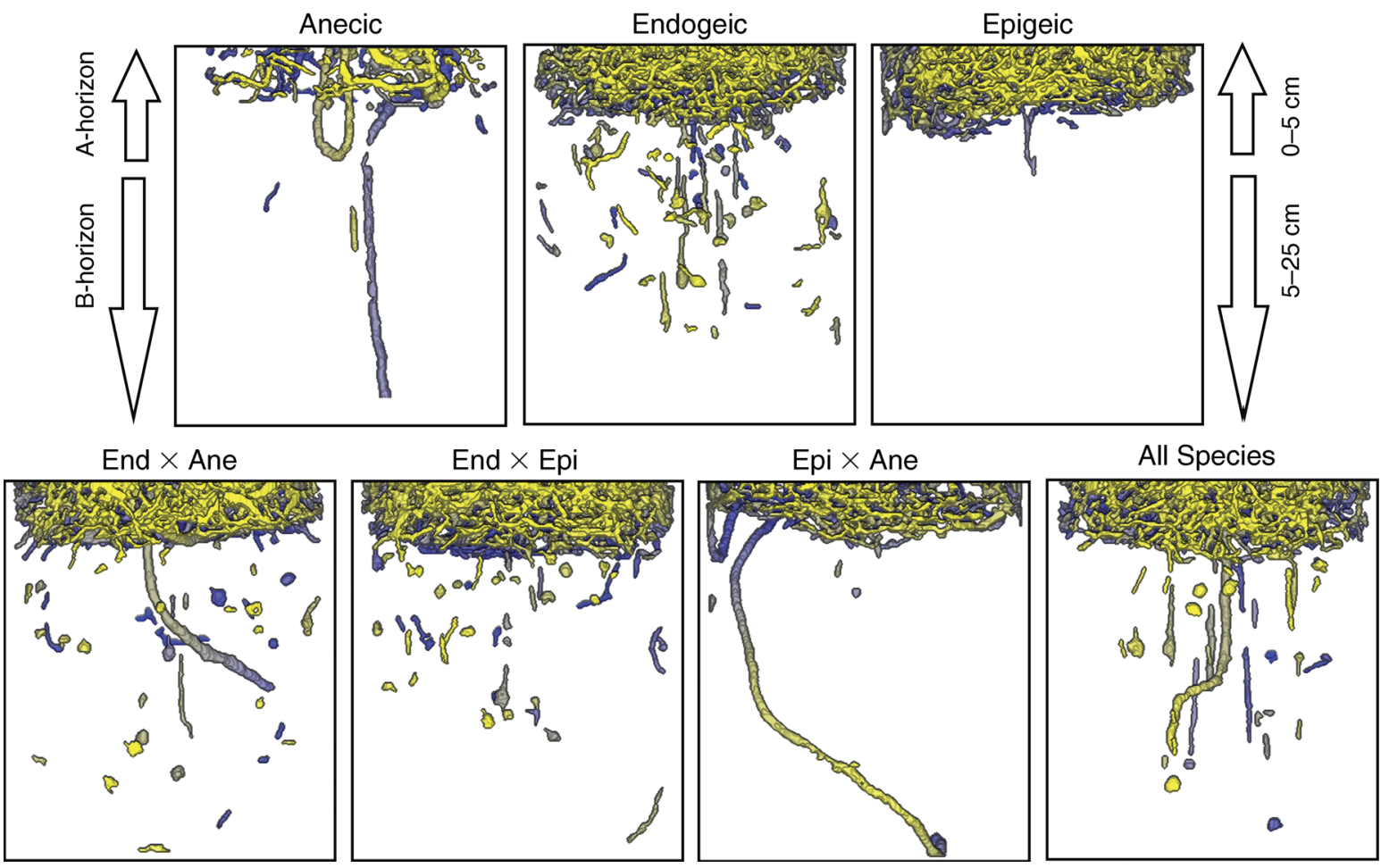

FIG. 1. Examples of three-dimensional reconstructions of earthworm community burrow systems imaged by X-ray computed tomography (CT). Color gradations represent the distance of burrows relative to the viewer's perspective (yellow for the foreground to blue for the background). Earthworm species of different functional groups included: Lumbricus terrestris (anecic [Ane]), Aporrectodea trapezoides (endogeic [End]), and Eisenia fetida (epigeic [Epi]).

(Dray and Dufour 2007), Hmisc (Harrell 2012), lattice (Sarkar 2008), and pgirmess (Giraudoux 2012).

\section{Results}

\section{Cumulative $\mathrm{CO}_{2}-\mathrm{C}$ and $\mathrm{DOC}$ loss}

Rates of respiratory $\mathrm{CO}_{2}$ loss decreased after the first six weeks of the experiment as winter temperatures decreased (Fig. 2A). We found no significant differences in total $\mathrm{CO}_{2}$ loss across treatments at the end of the oneyear incubation period (Kruskal-Wallis $H$ test, $P>$ $0.05)$. When mesocosms were destructively harvested at the end of the experiment, we found no adult earthworms and juvenile biomass accounted for $<1 \%$ of initial earthworm biomass. To evaluate differences in cumulative $\mathrm{CO}_{2}$ and DOC loss over time, we thereby restricted data analysis to the first 45 days of the experiment when temperature was above $20^{\circ} \mathrm{C}$, earthworm mortality and reproduction were likely low, and treatment variance was uniform. Earthworm treatments significantly affected $\mathrm{CO}_{2}$ loss over the first 45 days (GLM with repeated measures, $P=0.042$ ). The Endogeic $\times$ Epigeic treatment lost significantly more $\mathrm{CO}_{2}$ than the control, Endogeic Alone, and Epigeic Alone treatments (Bonferroni test, $P<0.05$ ). The Epigeic Alone and Endogeic Alone treatments had the lowest rates of $\mathrm{CO}_{2}$ loss, and were similar to $\mathrm{CO}_{2}$ loss in controls (Bonferroni test, $P>0.05$ ). Total $\mathrm{CO}_{2}$ loss was
4.54-6.16\% of total C, and was similar across treatments (Kruskal-Wallis $H$ test, $P>0.05$ ). DOC loss increased over time (GLM with repeated measures, $P=$ 0.049), though no significant effects of earthworm treatments were detected (Kruskal-Wallis $H$ test, $P>$ 0.05). Total DOC loss was three orders of magnitude lower than $\mathrm{CO}_{2}$ (Fig. 2B), and represented $<0.01 \%$ of total initial $\mathrm{C}$.

\section{Leaf litter and Soil C}

Earthworm community composition significantly affected leaf litter C loss (Fig. 3; Appendix B: Table B1). Leaf litter $\mathrm{C}$ remaining in treatments including anecic species was $33-39 \%$ less than in controls, but only $4-9 \%$ less where anecic species were absent. Two leaf litter types lost significant C: A. rubrum and P. grandidentata (Kruskal-Wallis $H$ tests, $P<0.05$ ). Treatment and controls lost similar F. grandifolia, $P$. strobus, and $Q$. rubra leaf litter C (Kruskal-Wallis $H$ tests, $P>0.05$ ). Across treatments, the morphology of decayed leaf litter remaining at the soil surface was primarily petioles and mid-veins of $A$. rubrum and $P$. grandidentata litter, largely intact $F$. grandifolia and $Q$. rubra litter (i.e., most soft tissue, mid-veins, and petioles remained), and fully intact P. strobus litter.

A-horizon and B-horizon $\mathrm{C}$ mass, $\% \mathrm{C}, \% \mathrm{~N}$, and $\mathrm{C}: \mathrm{N}$ did not change significantly (Kruskal-Wallis $H$ tests, $P$ 

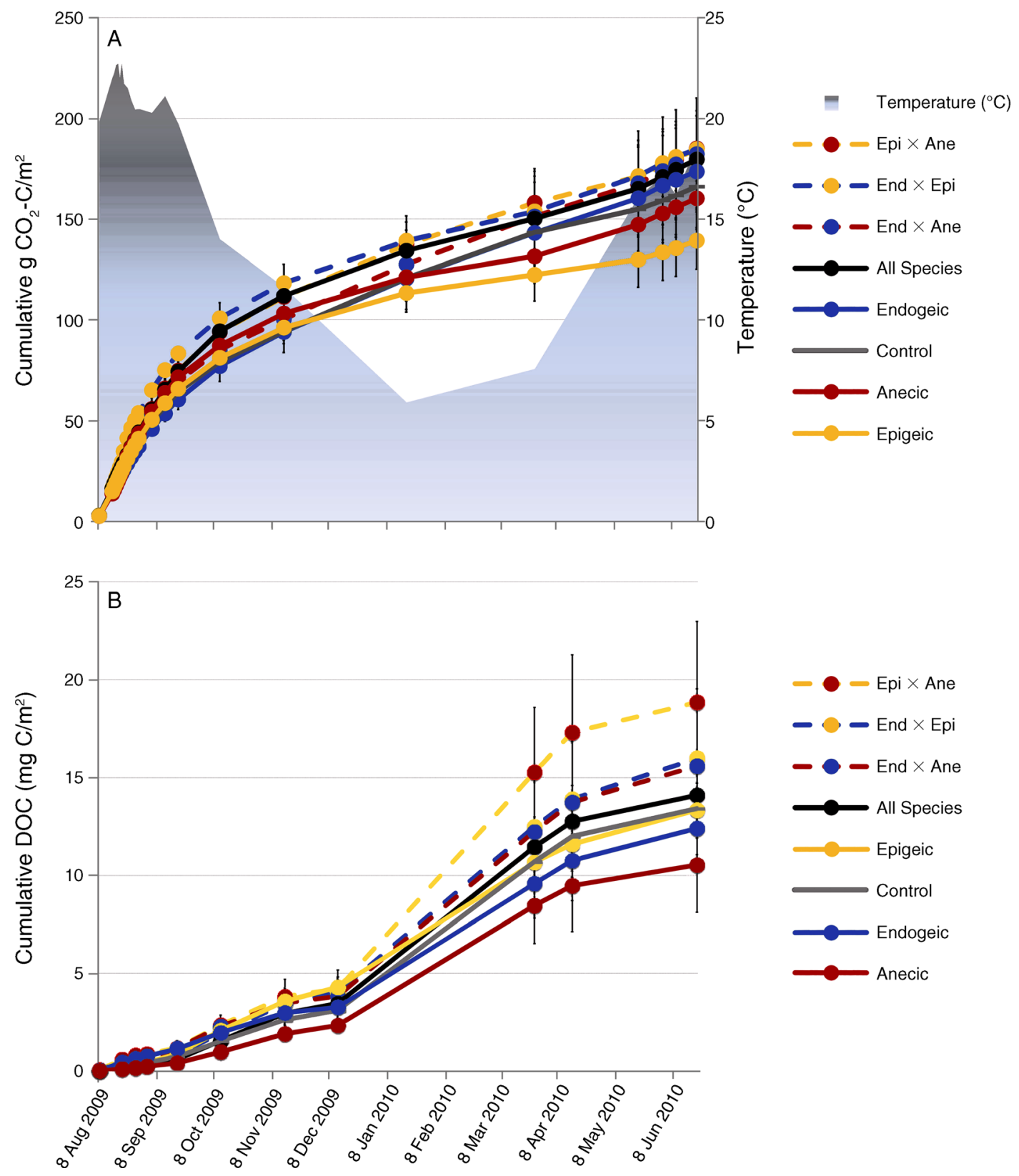

FIg. 2. (A) Cumulative soil $\mathrm{CO}_{2}-\mathrm{C}$ efflux and (B) cumulative dissolved organic carbon (DOC) efflux across earthworm treatments (see Fig. 1 for abbreviations). Values represent means, and vertical bars show \pm SE. Temperature $\left({ }^{\circ} \mathrm{C}\right)$ is shown in blue shades behind soil $\mathrm{CO}_{2}-\mathrm{C}$ efflux curves.

$>0.05)$. Burrow soil, which accounted for $2-5 \%$ of total soil $\mathrm{C}$ mass (Fig. 4), showed significantly higher $\% \mathrm{C}$ and $\% \mathrm{~N}$ values than non-burrow soils (Appendix $\mathrm{B}$ : Table B2). Burrow soil $\mathrm{C}$ content and $\% \mathrm{C}$ was positively correlated with A-horizon and leaf litter $\mathrm{C}$ content and \% . Total soil C, A-horizon C mass, Ahorizon $\% \mathrm{C}$, and were positively correlated with total $\mathrm{CO}_{2}$ loss. No significant correlations between soil $\mathrm{C}$ properties and DOC loss were observed (Appendix B: Table B3).

\section{Burrow system structure}

Across treatments, burrow system structure differed significantly in total macroporosity, A-horizon burrow volume, the continuity of burrows with vertical lengths $>3.75 \mathrm{~cm}$ (i.e., $0-15 \%$ of core length) and burrow size classes (Kruskal-Wallis $H$ tests, $P<0.05$; Appendix C: Table C1). Measures of burrow system structure, with the exception of burrow continuity classes characteristic of vertical burrowing activity by anecic species (25\% to 



FIg. 3. Final Fagus grandifolia (Fagr), Populus grandidentata (Pogr), Acer rubrum (Acru), and total leaf litter C mass across control, Anecic, Endogeic, Epigeic treatments (dark gray boxes), and multispecies earthworm treatments (light gray boxes). Horizontal gray bars show initial leaf litter $\mathrm{C}$ mass. Horizontal lines within boxes indicate median mass values for each leaf litter type; the first and third quartiles of the data (the interquartile range; IQR) are indicated by the top and bottom edges of each box; and extreme mass values (within 1.5 times the upper or lower quartile) are indicated by the ends of the lines extending from the IQR. Different lowercase letters indicate significant differences determined by Kruskal-Wallis $H$ tests with nonparametric multiple comparisons $(P<0.05)$. Pinus strobus and Quercus rubra losses are not shown. See Fig. 1 for abbreviations. 


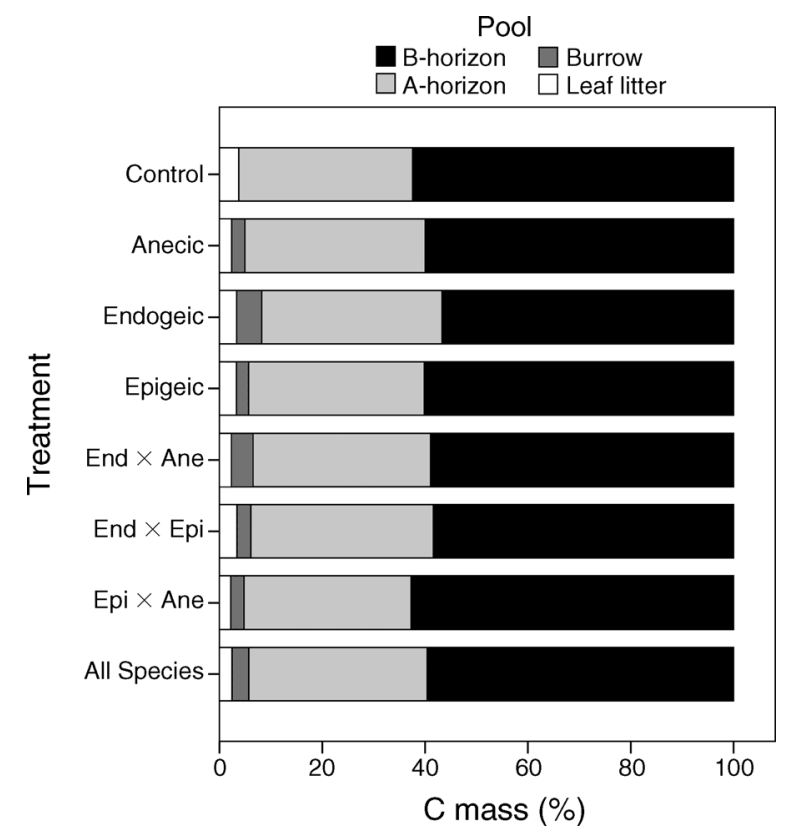

FIG. 4. Leaf litter and soil $\mathrm{C}$ pools expressed as the percentage of total $\mathrm{C}$ across the control and treatments (see Fig. 1 for abbreviations).

$>50 \%$ of core length), were highly correlated (Appendix $\mathrm{C}$ : Table C2).

Two axes (F1 and F2) of the co-inertia analysis explained $85.0 \%$ of the total variability in the burrow system structure and soil $\mathrm{C}$ budget components data costructure (Monte Carlo permutation tests, $P=0.007$;
Fig. 5). In the co-inertia factorial plane, projections of burrow system structure variables discriminated between burrow structure in the A-horizon and subsurface burrow structures in the B-horizon; projections of soil C budget components discriminated between leaf litter mass losses, A-horizon and burrow soil properties, and $\mathrm{C}$ losses as $\mathrm{CO}_{2}$ and DOC. Along F1 (59.2\% of total inertia), total macroporosity and burrow structures in the A-horizon (surface connectivity, burrow size classes, and burrow continuity classes $<25 \%$ of core length) were correlated with A-horizon and burrow soil $\mathrm{C}$ and $\mathrm{N}$ properties (C and $\mathrm{N}$ content, $\% \mathrm{C}$, and $\% \mathrm{~N}$ ). Along $\mathrm{F} 2$ (25.8\% of total inertia), burrow structures in the Bhorizon, characteristic of anecic species presence (i.e., burrow continuity classes $25-50 \%$ and $>50 \%$ of core length), were correlated with leaf litter mass losses (with the exception of $P$. strobus). $\mathrm{CO}_{2}$ and DOC losses were not correlated with burrow system properties.

\section{Soil C storage}

Inputs of $\mathrm{C}$ to soils from litter in control mesocosms $\left(25.0 \pm 4.59 \mathrm{~g} \mathrm{C} / \mathrm{m}^{2}\right.$ [mean $\left.\left.\pm \mathrm{SE}\right]\right)$ were less than $\mathrm{C}$ outputs as $\mathrm{CO}_{2}$ and DOC $\left(153 \pm 6.73 \mathrm{~g} \mathrm{C} / \mathrm{m}^{2}\right)$. As a result, soil $\mathrm{C}$ storage $(\Delta \mathrm{C})$ in controls was negative, representing a baseline net loss from the soil system (-128.52 \pm 11.31 g C/m² ; Fig. 6). Litter C inputs to soils were higher in all treatments with anecic species (MannWhitney $U$ tests, $P<0.05$ ), though $\mathrm{C}$ outputs did not differ significantly across control and earthworm treatments (Kruskal-Wallis $H$ test, $P>0.05$ ). Significant shifts in $\Delta \mathrm{C}$ were not detected, though a trend of greater
FIG. 5. Relationships between burrow system (dashed arrows, italicized text) and $\mathrm{C}$ budget measures (solid arrows, plain text) according to relative positions on the $\mathrm{Fl} \times \mathrm{F} 2$ co-inertia plane. Burrow system structure measures are: macroporosity (MR), surface connectivity (SC), size class (BS, defined as: $2,0.17$ to $<0.34 \mathrm{~cm}^{2} ; 3$, $\left.>0.34 \mathrm{~cm}^{2}\right)$, continuity class (BC, defined as: 1 , $0-15 \% ; 2,15-25 \% ; 3,25-50 \% ; 4,>50 \%)$. C budget components are: A. rubrum (Acru), $F$. grandifolia (Fagr), P. strobus (Pist), P. grandidentata (Pogr), Q. rubra (Quru), and total leaf litter $\mathrm{C}$ loss; A-horizon (A) and burrow $(\mathrm{Br}) \mathrm{C}$ and $\mathrm{N}$ properties $(\mathrm{C}: \mathrm{N}, \% \mathrm{~N}, \% \mathrm{C}$, and Cmass); and $\mathrm{CO}_{2}$ and DOC loss. Co-inertia axis eigenvalues are $\mathrm{F} 1=4.27$ and $\mathrm{F} 2=1.99$.

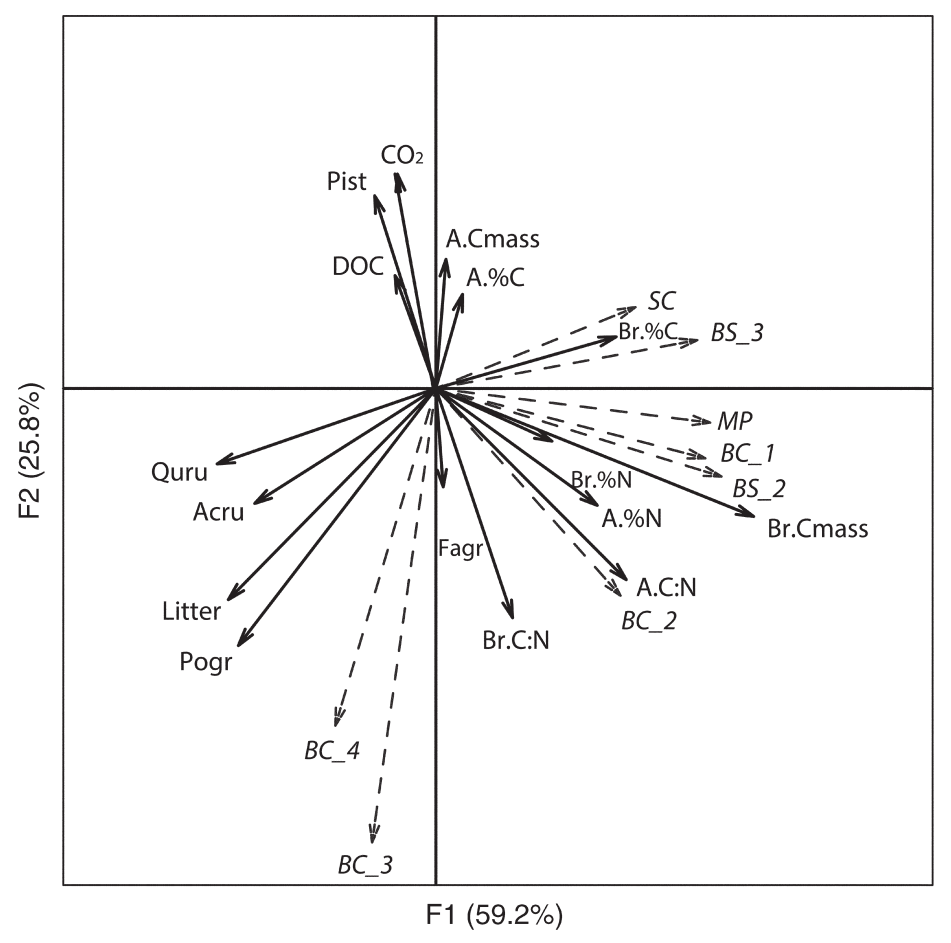




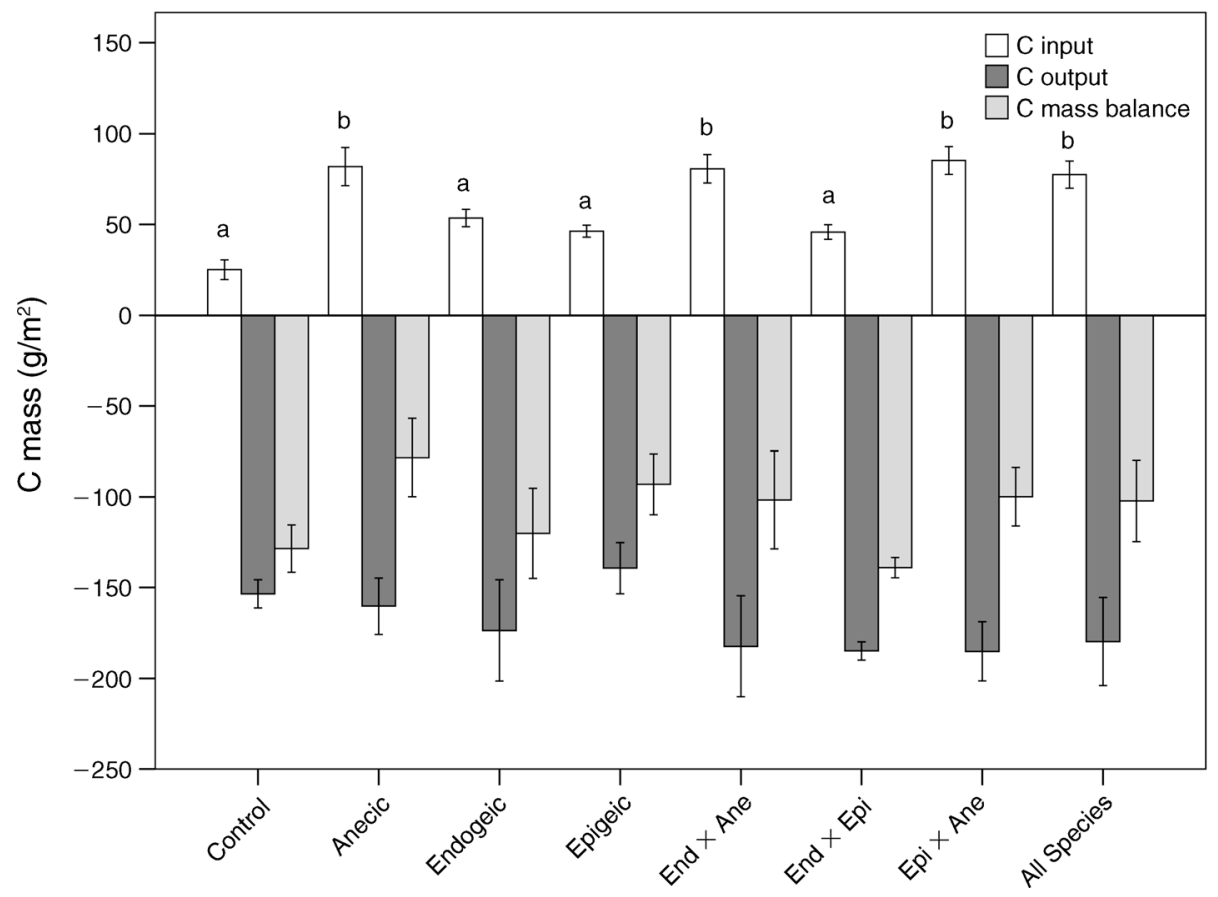

FIG. 6. C inputs, $\mathrm{C}$ outputs, and net $\mathrm{C}$ mass storage ( $\Delta C$; Eq. 2$)$ across the control and treatments. Lowercase letters represent significant differences determined by Kruskal-Wallis $H$ tests with nonparametric multiple comparisons $(P<0.05)$. C output and $\Delta C$ are similar across treatments.

$\Delta \mathrm{C}$ occurred across earthworm treatments (KruskalWallis $H$ test, $P>0.05$ ).

\section{DISCUSSION}

Our results suggest earthworm communities have important nonadditive effects on processes including soil $\mathrm{CO}_{2}$ loss and mediate leaf litter redistribution, soil C budget components, and soil physical structure. First, soil $\mathrm{CO}_{2}$ loss rates were highest during the first weeks of the experiment, though no differences in total $\mathrm{CO}_{2}$ or DOC loss were observed at the end of the incubation. As species monocultures had the lowest $\mathrm{CO}_{2}$ efflux rates, significant increases in $\mathrm{CO}_{2}$ efflux rates in multispecies treatments suggests enhanced access to $\mathrm{C}$ resources by functional groups. Previous studies show increased soil $\mathrm{CO}_{2}$ losses of $7-58 \%$, following earthworm invasions in forest soils (e.g., Borken et al. 2000, Speratti et al. 2007) attributed to leaf litter incorporation into soil, highly localized organic matter redistribution, and increased microbial respiration in casts and burrow soils (Scheu 1987, Wolters and Joergensen 1992, Tiunov and Scheu 1999, Brown et al. 2000). DOC loss represented $<0.01 \%$ of total $\mathrm{C}$ and showed no response to earthworm treatments, in contrast to a $50 \%$ reduction in DOC loss from earthworm-invaded forest soils observed by Bohlen et al. (2004a). In our study, low DOC losses could be due to root exclusion, which removed root exudates and decay as sources of DOC outputs, and possible adsorption of DOC transported from Ahorizon to B-horizon soils (Currie et al. 1996, Kaiser and Zech 1998, Kalbitz et al. 2000). It is unlikely that C redistribution and burrow system differences were generated during winter months when earthworm activity is lowest and differential mortality and reproduction occur (Lee 1985, Edwards and Bohlen 1996, Callaham and Hendrix 1997, Uvarov et al. 2011). Observed patterns of early, rapid C losses are thereby consistent with burrow system production and organic matter redistribution in the first weeks of our experiment. Further, lower rates of $\mathrm{C}$ losses and increased variability within treatment replicates with time are consistent with differential mortality, reproduction, or activity during fall and winter months.

Earthworm-mediated litter decomposition is determined by rates of litter comminution, consumption, and translocation into soils (Shipitalo and Protz 1989, Edwards and Bohlen 1996), and constrained by leaf litter chemistry and earthworm food preference (Reich et al. 2005, Hobbie et al. 2006, Suárez et al. 2006, Holdsworth et al. 2008). Our results showed leaf litter C loss increased by $33-39 \%$ in communities containing the anecic species, and differential mass loss and morphology of decayed leaf litter types (A. rubrum $>P$. grandidentata $>F$. grandifolia $\geq Q$. rubra $>$ P. strobus). Enhanced leaf litter decomposition with earthworm invasions has been widely observed in temperate forests (Scheu and Wolters 1991, Suárez et al. 2006, Holdsworth et al. 2008, Zicsi et al. 2011). Higher losses reported in field studies may be due to higher earthworm densities, longer observation periods, and the larger 
community of soil invertebrates. For example, Suárez et al. (2006) observed leaf litter remaining in earthworminvaded plots was 1.7-3.0 times less than in reference plots in a hardwood forest after 540 days. Holdsworth et al. (2008) observed increased litter mass loss from coarse-meshed litter bags, which allowed enhanced access and leaf litter translocation by the broader soil invertebrate community.

In contrast to our prediction, significant changes in $\mathrm{C}$ storage were not linked to earthworm community composition, although $\mathrm{C}$ storage generally decreased across treatments. Lack of significant changes in soil $\mathrm{C}$ storage could be attributed to earthworm density and activity (because burrow soils only accounted for up to $5 \%$ of soil C mass), incubation time, and land use history. For example, Alban and Berry (1994) observed earthworm density increases over a 13-year period, the concurrent development of an A-horizon, and increased mineral soil \%C. Bohlen et al. (2004a) demonstrated land-use history as a factor constraining earthworm invasion impacts on soil $\mathrm{C}$ pools, finding no influence of earthworm invasions on soil $\mathrm{C}$ storage at a previously cultivated forest site with low forest floor accumulation rates. A $28 \%$ reduction in soil C storage and reduced soil $\mathrm{C}: \mathrm{N}$ ratios were, however, observed in undisturbed forest sites of similar earthworm density (Bohlen et al. 2004a). Past disturbances of logging and wildfires constrain soil $\mathrm{C}$ storage rates in these forests (Gough et al. 2008), and with earthworm density and time, may constrain the impact of earthworm communities on soil C budgets.

Our results partially support the prediction that burrow system properties would be directly related to shifts in $\mathrm{C}$ redistribution. Burrow system structures differed significantly across earthworm treatments and were in agreement with the known behavior of the different ecological groups (Bastardie et al. 2005). Somewhat surprisingly, burrow systems did not affect $\mathrm{CO}_{2}$ or DOC loss, showing no evidence of increased soil $\mathrm{C}$ losses with greater soil porosity. This may be attributed to the well-drained nature of these soils, where $\mathrm{C}$ losses are controlled by production rather than diffusion or infiltration rates. However, subsurface burrow systems were associated with vertical redistribution of litter-derived organic material into the Ahorizon, as indicated by strong correlations between (1) subsurface burrows characteristic of vertical burrowing by anecic species, and leaf litter mass losses (with the exception of $P$. strobus); and (2) dense burrow networks in the A-horizon and the $\mathrm{C}$ and $\mathrm{N}$ properties of these pools.

In sandy soils, it appears earthworm community composition and associated burrow system structures mediate litter translocation and soil physical structure, altering soil organic matter inputs while having modest impacts on $\mathrm{C}$ losses in the short term. This outcome suggests the net effects of earthworm communities on the primary carbon pools and fluxes in these soils is moderate, with the expected increases in leaf litter translocation and burrow system formation, but with minimal or no significant effects on carbon outputs and annual carbon storage. However, as our experiment excluded plant and root exudates, both significant drivers of belowground forest $\mathrm{C}$ cycling (Nadelhoffer and Raich 1992, Andrews et al. 1999, Gaudinski et al. 2000), our ability to extrapolate to earthworm invasions impacts under in situ conditions is limited. Overall, this work contributes to the process-level understanding of how earthworm species interactions modify factors that ultimately determine soil C storage across forest ecosystems. Future studies with increased observation times and comparative studies that manipulate both earthworm species diversity and forest soil types would build on this baseline understanding of the net impacts of earthworm communities on forest soil $\mathrm{C}$ storage.

\section{ACKNOWLEDGments}

We thank M. Grant for analytical services; C. Vogel for AmeriFlux field data; and B. Carson, P. Rink, R. Spray, T. Sutterly, and S. Webster for preparatory support. The NSF Doctoral Dissertation Improvement Grant 1110494, the NSFIGERT Biosphere Atmosphere Research and Training Program (NSF-IGERT-0504552), and the University of Michigan Rackham Graduate School and Department of Ecology and Evolutionary Biology funded this research.

\section{Literature Cited}

Alban, D. H., and E. C. Berry. 1994. Effects of earthworm invasion on morphology, carbon, and nitrogen of a forest soil. Applied Soil Ecology 1:243-249.

Andrews, J. A., K. G. Harrison, R. Matamala, and W. H. Schlesinger. 1999. Separation of root respiration from total soil respiration using carbon-13 labeling during free-air carbon dioxide enrichment (FACE). Soil Science Society of America Journal 63:1429-1435.

Araujo, Y., F. J. Luizao, and E. Barros. 2004. Effect of earthworm addition on soil nitrogen availability, microbial biomass and litter decomposition in mesocosms. Biology and Fertility of Soils 39:146-152.

Bastardie, F., Y. Capowiez, and D. Cluzeau. 2005. 3D characterisation of earthworm burrow systems in natural soil cores collected from a 12-year-old pasture. Applied Soil Ecology 30:34-46.

Bohlen, P. J., D. M. Pelletier, P. M. Groffman, T. J. Fahey, and M. C. Fisk. 2004a. Influence of earthworm invasion on redistribution and retention of soil carbon and nitrogen in northern temperate forests. Ecosystems 7:13-27.

Bohlen, P. J., S. Scheu, C. M. Hale, M. A. McLean, S. Migge, P. M. Groffman, and D. Parkinson. 2004b. Non-native invasive earthworms as agents of change in northern temperate forests. Frontiers in Ecology and the Environment 2:427-435.

Borken, W., S. Grundel, and F. Beese. 2000. Potential contribution of Lumbricus terrestris L. to carbon dioxide, methane and nitrous oxide fluxes from a forest soil. Biology and Fertility of Soils 32:142-148.

Bouché, M. B. 1977. Strategies lombriciennes. Pages 122-132 in U. Lohm and T. Persson, editors. Soil organisms as components of ecosystems. Ecological Bulletins, Stockholm, Sweden.

Brown, G. G., I. Barois, and P. Lavelle. 2000. Regulation of soil organic matter dynamics and microbial activity in the drilosphere and the role of interactions with other edaphic functional domains. European Journal of Soil Biology 36: $177-198$. 
Burtelow, A. E., P. J. Bohlen, and P. M. Groffman. 1998. Influence of exotic earthworm invasion on soil organic matter, microbial biomass and denitrification potential in forest soils of the northeastern United States. Applied Soil Ecology 9:197-202.

Callaham, M. A., and P. F. Hendrix. 1997. Relative abundance and seasonal activity of earthworms (Lumbricidae and Megascolecidae) as determined by hand-sorting and formalin extraction in forest soils on the southern Appalachian Piedmont. Soil Biology and Biochemistry 29:317-321.

Capowiez, Y., P. Monestiez, and L. Belzunces. 2001. Burrow systems made by Aporrectodea nocturna and Allolobophora chlorotica in artificial cores: morphological differences and effects of interspecific interactions. Applied Soil Ecology 16: 109-120.

Capowiez, Y., S. Sammartino, and E. Michel. 2011. Using Xray tomography to quantify earthworm bioturbation nondestructively in repacked soil cores. Geoderma 162:124-131.

Castro, M. S., P. A. Steudler, J. M. Melillo, J. D. Aber, and R. D. Bowden. 1995. Factors controlling atmospheric methane consumption by temperate forest soils. Global Biogeochemical Cycles 9:1-10.

Costello, D. M., and G. A. Lamberti. 2009. Biological and physical effects of non-native earthworms on nitrogen cycling in riparian soils. Soil Biology and Biochemistry 41:22302235.

Currie, W. S., J. D. Aber, W. H. McDowell, R. D. Boone, and A. H. Magill. 1996. Vertical transport of dissolved organic C and $\mathrm{N}$ under long-term $\mathrm{N}$ amendments in pine and hardwood forests. Biogeochemistry 35:471-505.

Curry, J. P., and O. Schmidt. 2006. The feeding ecology of earthworms: A review. Pedobiologia 50:463-477.

Davidson, E. A., E. Belk, and R. D. Boone. 1998. Soil water content and temperature as independent or confounded factors controlling soil respiration in a temperate mixed hardwood forest. Global Change Biology 4:217-227.

Doledec, S., and D. Chessel. 1994. Co-inertia analysis: An alternative method for studying species environment relationships. Freshwater Biology 31:277-294.

Dray, S., D. Chessel, and J. Thioulouse. 2003. Co-inertia analysis and the linking of ecological data tables. Ecology 84: 3078-3089.

Dray, S., and A. B. Dufour. 2007. The ade4 package: implementing the duality diagram for ecologists. Journal of Statistical Software 22:1-20.

Edwards, C. A., and P. J. Bohlen. 1996. Biology and ecology of earthworms. Chapman and Hall, London, UK.

Eisenhauer, N., S. Partsch, D. Parkinson, and S. Scheu. 2007. Invasion of a deciduous forest by earthworms: Changes in soil chemistry, microflora, microarthropods and vegetation. Soil Biology and Biochemistry 39:1099-1110.

Fisk, M. G., T. J. Fahey, P. M. Groffman, and P. J. Bohlen. 2004. Earthworm invasion, fine-root distributions, and soil respiration in North temperate forests. Ecosystems 7:55-62.

Frelich, L. E., C. M. Hale, S. Scheu, A. R. Holdsworth, L. Heneghan, P. J. Bohlen, and P. B. Reich. 2006. Earthworm invasion into previously earthworm-free temperate and boreal forests. Biological Invasions 8:1235-1245.

Gaudinski, J. B., S. E. Trumbore, E. A. Davidson, and S. Zheng. 2000. Soil carbon cycling in a temperate forest: radiocarbon-based estimates of residence times, sequestration rates and partitioning of fluxes. Biogeochemistry 51:33-69.

Giraudoux, P. 2012. pgirmess: data analysis in ecology. R Package version 1.5.6. R Foundation for Statistical Computing, Vienna, Austria. http://CRAN.R-project.org/ package=pgirmess

Gough, C. M., C. S. Vogel, H. P. Schmid, and P. S. Curtis 2008. Controls on annual forest carbon storage: Lessons from the past and predictions for the future. Bioscience 58: 609-622.
Hale, C. M., L. E. Frelich, and P. B. Reich. 2005. Exotic European earthworm invasion dynamics in northern hardwood forests of Minnesota, USA. Ecological Applications 15:848-860.

Hale, C. M., L. E. Frelich, and P. B. Reich. 2006. Changes in hardwood forest understory plant communities in response to European earthworm invasions. Ecology 87:1637-1649.

Harrell, F. E. 2012. Hmisc: Harrell miscellaneous package. R package version 3.10-1. Foundation for Statistical Computing, Vienna, Austria. http://CRAN.R-project.org/ package $=$ Hmisc

Hobbie, S. E., P. B. Reich, J. Oleksyn, M. Ogdahl, R. Zytkowiak, C. Hale, and P. Karolewski. 2006. Tree species effects on decomposition and forest floor dynamics in a common garden. Ecology 87:2288-2297.

Holdsworth, A. R., L. E. Frelich, and P. B. Reich. 2007. Regional extent of an ecosystem engineer: earthworm invasion in northern hardwood forests. Ecological Applications 17:1666-1677.

Holdsworth, A. R., L. E. Frelich, and P. B. Reich. 2008. Litter decomposition in earthworm-invaded northern hardwood forests: Role of invasion degree and litter chemistry. Ecoscience 15:536-544.

James, S. W. 1995. Systematics, biogeography, and ecology of nearctic earthworms from eastern, central, southern and southwestern United States. Pages 29-52 in P. F. Hendrix, editor. Earthworm ecology and biogeography in North America. Lewis Publishers, Boca Raton, Florida, USA.

Jégou, D., D. Cluzeau, J. Balesdent, and P. Trehen. $1998 a$. Effects of four ecological categories of earthworms on carbon transfer in soil. Applied Soil Ecology 9:249-255.

Jégou, D., D. Cluzeau, V. Hallaire, J. Balesdent, and P. Trehen. 2000. Burrowing activity of the earthworms Lumbricus terrestris and Aporrectodea giardi and consequences on C transfers in soil. European Journal of Soil Biology 36:27-34.

Jégou, D., D. Cluzeau, H. J. Wolf, Y. Gandon, and P. Trehen. 1998b. Assessment of the burrow system of Lumbricus terrestris, Aporrectodea giardi, and Aporrectodea caliginosa using X-ray computed tomography. Biology and Fertility of Soils 26:116-121.

Kaiser, K., and W. Zech. 1998. Rates of dissolved organic matter release and sorption in forest soils. Soil Science 163: $714-725$.

Kalbitz, K., S. Solinger, J. H. Park, B. Michalzik, and E. Matzner. 2000. Controls on the dynamics of dissolved organic matter in soils: A review. Soil Science 165:277-304.

Lee, K. E. 1985. Earthworms: their ecology and relationships with soils and land use. Academic Press, Sydney, Australia.

Le Mer, J., and P. Roger. 2001. Production, oxidation, emission and consumption of methane by soils: A review. European Journal of Soil Biology 37:25-50.

Lussenhop, J., R. Fogel, and K. Pregitzer. 1991. A new dawn for soil biology: Video analysis of root soil microbial faunal interactions. Agriculture Ecosystems and Environment 34: 235-249.

Marhan, S., and S. Scheu. 2006. Mixing of different mineral soil layers by endogeic earthworms affects carbon and nitrogen mineralization. Biology and Fertility of Soils 42:308-314.

Nadelhoffer, K. J., and J. W. Raich. 1992. Fine root production estimates and belowground carbon allocation in forest ecosystems. Ecology 1139-1147.

Pierret, A., Y. Capowiez, L. Belzunces, and C. J. Moran. 2002. $3 \mathrm{D}$ reconstruction and quantification of macropores using $\mathrm{X}$ ray computed tomography and image analysis. Geoderma 106:247-271

Postma-Blaauw, M. B., J. Bloem, J. H. Faber, J. W. van Groenigen, R. G. M. de Goede, and L. Brussaard. 2006. Earthworm species composition affects the soil bacterial community and net nitrogen mineralization. Pedobiologia 50: 243-256. 
R Development Core Team. 2012. R: a language and environment for statistical computing. R Foundation for Statistical Computing, Vienna, Austria.

Reich, P. B., et al. 2005. Linking litter calcium, earthworms and soil properties: a common garden test with 14 tree species. Ecology Letters 8:811-818.

Sackett, T. E., S. M. Smith, and N. Basiliko. 2012. Indirect and direct effects of exotic earthworms on soil nutrient and carbon pools in North American temperate forests. Soil Biology and Biochemistry 57:459-467.

Sarkar, S. 2008. Lattice: multivariate data visualization with R. Springer Science+Business Media, New York, New York, USA.

Scheu, S. 1987. Microbial activity and nutrient dynamics in earthworm casts (Lumbrucidae). Biology and Fertility of Soils 5:230-234.

Scheu, S. 1997. Effects of litter (beech and stinging nettle) and earthworms (Octolasion lacteum) on carbon and nutrient cycling in beech forests on a basalt-limestone gradient: A laboratory experiment. Biology and Fertility of Soils 24:384393.

Scheu, S., and V. Wolters. 1991. Influence of fragmentation and bioturbation on the decomposition of C-14-labeled beech leaf litter. Soil Biology and Biochemistry 23:1029-1034.

Shipitalo, M., and R. Protz. 1989. Chemistry and micromorphology of aggregation in earthworm casts. Geoderma 45: 357-374.

Speratti, A. B., J. K. Whalen, and P. Rochette. 2007. Earthworm influence on carbon dioxide and nitrous oxide fluxes from an unfertilized corn agroecosystem. Biology and Fertility of Soils 44:405-409.

Straube, D., E. A. Johnson, D. Parkinson, S. Scheu, and N. Eisenhauer. 2009. Nonlinearity of effects of invasive ecosystem engineers on abiotic soil properties and soil biota. Oikos 118:885-896.

Suárez, E. R., T. J. Fahey, P. M. Groffman, J. B. Yavitt, and P. J. Bohlen. 2006. Spatial and temporal dynamics of exotic earthworm communities along invasion fronts in a temperate hardwood forest in south-central New York (USA). Biological Invasions 8:553-564.

Tiunov, A. V., and S. Scheu. 1999. Microbial respiration, biomass, biovolume and nutrient status in burrow walls of Lumbricus terrestris L. (Lumbricidae). Soil Biology and Biochemistry 31:2039-2048.

Toland, D., and D. Zak. 1994. Seasonal patterns of soil respiration in intact and clear-cut northern hardwood forests. Canadian Journal of Forest Research 24:1711-1716.

Uvarov, A. V. 2009. Inter- and intraspecific interactions in lumbricid earthworms: Their role for earthworm performance and ecosystem functioning. Pedobiologia 53:1-27.

Uvarov, A. V., A. V. Tiunov, and S. Scheu. 2011. Effects of seasonal and diurnal temperature fluctuations on population dynamics of two epigeic earthworm species in forest soil. Soil Biology and Biochemistry 43:559-570.

Whalen, J. K., and C. Costa. 2003. Linking spatio-temporal dynamics of earthworm populations to nutrient cycling in temperate agricultural and forest ecosystems. Pedobiologia 47:801-806.

Wironen, M., and T. R. Moore. 2006. Exotic earthworm invasion increases soil carbon and nitrogen in an old-growth forest in southern Quebec. Canadian Journal of Forest Research 36:845-854.

Wolters, V. 2000. Invertebrate control of soil organic matter stability. Biology and Fertility of Soils 31:1-19.

Wolters, V., and R. Joergensen. 1992. Microbial carbon turnover in beech forest soils worked by Aporrectodea caliginosa (Savigny) (Oligochaeta, Lumbricidae). Soil Biology and Biochemistry 24:171-177.

Zicsi, A., K. Szlavecz, and C. Csuzdi. 2011. Leaf litter acceptance and cast deposition by peregrine and endemic European lumbricids (Oligochaeta: Lumbricidae). Pedobiologia 54:S145-S152.

\section{Supplementary Material}

\section{Appendix A}

Description of the study area (Ecological Archives E094-261-A1).

\section{Appendix B}

Tables showing numerical values of soil $\mathrm{C}$ budget variables (leaf litter mass loss, post-treatment soil $\mathrm{C}$ and $\mathrm{N}$ properties) across treatments, and a figure showing Spearman rank correlations (Ecological Archives E094-261-A2).

\section{Appendix C}

Tables showing numerical values of burrow system structure properties (macrostructure, continuity, size distribution) across treatments, and a figure showing Spearman rank correlations (Ecological Archives E094-261-A3). 